\title{
PENGARUH MARKET VALUE ADDED (MVA) DAN RASIO PROFITABILITAS TERHADAP NILAI PERUSAHAAN PADA PERUSAHAAN MANUFAKTUR
}

\author{
${ }^{1}$ Desi Permata Sari, ${ }^{2}$ Zufrizal Harahap, ${ }^{3}$ Farida Khairani Lubis, ${ }^{4}$ Shofwan Andri \\ ${ }_{1,2,3,4}$ Universitas Islam Islam Sumatera Utara \\ Idesipermatas0527@gmail.com, 2zurfizal@uisu.ac.id,33arida.khairanilubis@gmail.com, \\ ${ }^{4}$ shofwan.andri@fe.uisu.ac.id
}

\begin{abstract}
This study aims to determine the effect of market value added,and profitability ratios, on firm value partially and simultaneously in building construction sub-sector manufacturing companies listed on the Indonesia Stock Exchange. The population in this study were 56 companies and the samples in this study were 19 manufacturing companies listed on the Indonesia Stock Exchange with an observation period of 3 years to 57. This study uses secondary data. The data collected is data from manufacturing sector companies listed on the Indonesia Stock Exchange.Data analysis using multiple linear regression. The results showed that market value added had a positive dan significant effect on price to book value, return on equity had a positive and significant effect on price to book value and jointly the market value added and return on equity variables had a positive and significant effect on price to book value.
\end{abstract}

Keywords: Market Value Added, Return On Equity, Price To Book Value

ABSTRAK : Penelitian ini bertujuan untuk mengetahui pengaruh Market value added, dan Rasio Profitabilitas, terhadap nilai perusahaan pada perusahaan sub ssektor manufaktur di BEI. Populasi dalam penelitian ini adalah 56 perusahaan dan yang menjadi sampel dalam penelitian ini berjumlah 19 perusahaan yang terdaftar di BEI dengan periode pengamatan 3 tahun menjadi 57.Penelitian ini menggunakan data sekunder.Data yang dikumpulkan adalah data yang berasal dari perusahaan Manufaktur yang terdapat di BEI.Analisis data menggunakan regresi linier berganda.Hasil penelitian menunjukkan bahwa market value added berpengaruh positif dan signifikan terhadap price to book value, return on equity berpengaruh positif dan signifikan terhadap price to book value serta secara bersama-sama variabel market value added dan return on equity berpengaruh positif dan signifikan terhadap price to book value.

Kata kunci : Market Value Added, Return On Equity, Price To Book Value

\section{Pendahuluan}

Perusahaan pada dasarnya ingin berupaya untuk men dapatkan tujuan dari perusahaan tersebut, baik tujuan jangka pendek yaitu meningkatkan penghasilan perusahaan maupun jangka panjang yaitu menumbuhkan nilai perusahaan dan men sejahterakan pemilik saham. Memikat pandangan investor terhadap perusahaan adalah tujuan me ningkatkan nilai perusahaan (Pramana dan Mustanda, 2016). Nilai perusahaan atau industri dapat diartikan sebagai biaya yang mampu dibayarkan oleh calon penawar ketika perusahaan tersebut di jual. Perusaha an go publik seperti perusahaan pada sub sektor kontruksi dan bangunan ini telah menyampaikan saham ke public atau umum, maka dapat disimpulkan bahwa nilai suatu perusahaan dapat di artikan sebagai tanggapan seorang investor mengenai industri itu sendiri (Sintyana dan Artini, 2019).

Nilai perusahaan yang besar akan menjadikan rasa keinginan seorang penanam modal akan meningkat, baik kinerja perusahaan saat ini maupun prospek perusahaan di masa yang akan datang. Investor bisa menggunakan nilai industri sebagai alat untuk menilai kinerja perusahaan di masa yang akan datang. Seiring dengan pertumbuhan ilmu pengetahuan atau pandangan terhdap sebuah kinerja perusahaan tidak hanya di nilai dari rasio keuangan saja, melainkan dengan metode baru yang di gunakan untuk meng hitung performa operasional perusahaan dengan mengamati keperluan dan harapan pemberi dana atau kreditor dan pemegang saham, yang 
dapat disebut dengan "Market Value Added (MVA)".

Market value added (nilai tambah pasar) meng gambarkan peningkatan nilai pasar suatu perusahaan yang dilakukan dengan meningkatkan jarak antara nilai pasar modal dengan total yang ditanamkan pemberi dana ke dalam perusaha an. Selain metode Market value added yang bisa di gunakan untuk menaksir performa perusahan, rasio keuangan juga bisa digunakan untuk mengkaji laporan keuangan yang digunakan untuk menilai kinerja industry atau perusaha an tersebut dalam keadaan baik atau buruk. Teknik yang dapat di gunakan adalah Return on Equity yang disingkat ROE. ROE adalah gambaran perusaha an dalam meng hasilkan keuntungan yang besar bagi para pemegang saham, yang akan berdampak pada nilai perusahaan. Nilai ROE yang besar akan memberikan dampak sinyal positif bagi para pemberi dana untuk membeli saham perusaha an,kenaikan perminta an saham tersebut akan me ningkatkan harga saham, harga saham yang meningkat kemudian akan ber dampak pada peningkatan nilai perusaha an.

\section{Landasan Teori}

\subsection{Signaling Theory}

Signaling theory adalah teori yang menyatakan tentang sinyal-sinyal yang timbul dari suatu ketentuan atau ketetapan yang dilakukan perusaha an (Fahmi, 2015:110) atau "signaling theory "merupakan konsep yang menggambarkan tentang suatu kondisi pada perusahaan. Salah satu -tanda yang dijelaskan oleh perusaha an yaitu berbentuk laporan keuangan. Dimana tujuan utama laporan keuangan, merupakan informasi yang mengenai kinerja perusahaan yang ter sedia di dalam laporan keuangan dengan me ngukur laba dan komponen nya(Fahmi, 2015:20). Di suatu laporan keuangan me miliki berbagai teknik rasio yang menjelaskan kinerja perusahaan tersebut di antaranya yaitu rasio profitabilitas , atau bisa juga diartikan sebagai rasio yang melihatkan keuntungan yang di peroleh perusaha an. Di mana jika "rasio profitabilitas" suatu perusaha an besar akan memberikan dampak sinyal positif bagi investor sehingga pemberi dana akan melakukan kenaikan permintaan saham yang me nyebabkan harga saham mengalami penambahan dan juga nilai perusahaan mendapati peningkatan.

\subsection{Nilai Perusahaan}

Nilai perusaha an adalah cerminan me ngenai keadaan perusaha an. Nilai perusaha an di amati sebagai suatu yang amat sangat penting di karena dengan nilai perusaha an yang tinggi, maka akan dapat memberikan dampak bagi kemakmuran para pemilik saham. Nilai perusaha an yang tinggi dapat meningkat kan kenyamanan bagi para pemegang saham, se hingga para pemilik saham akan meng investasikan modal nya kepada perusaha an tersebut (Suroto, 2018:99).Nilai perusaha an dalam penelitian ini di hitung dengan meng gunakan "Price to book value" (PBV) dimana PBV menunjukkan se berapa tinggi pasar me mandang nilai buku saham suatu perusaha an, "semakin tinggi rasio nya maka semakin tinggi pula perusaha an dinilai bagi para pemberi dana. Sedangkan nilai buku (Book Value) adalah nilai bersih yang di miliki pemegang saham dari hasil rasio dengan membagi total asset bersih dengan total saham yang beredar (Hermuningsih dan Wardani, 2009)". Adapun rumus untuk menghitung PBV sebagai berikut:

$P B V=\frac{\text { Harga } \text { Saham }}{\text { Nilai } B u k u}$

\subsection{Market Value Added"}

Market value added atau MVA adalah perbedaan nilai pasar perusaha an dengan modal (equity) yang di investasikan (Keown dkk, 2010:35)". Dengan begitu,"Market value added adalah pe mikirian dari keinginan pemegang dana atas nilai yang mereka inginkan dari perusaha an untuk menghasilkan nilai masa yang akan datang dengan meningkatkan selisih antara lain pasar ekuitas/modal dengan modal sendiri yang di berikan ke perusaha an oleh para pemegang saham (pemilik perusahaan). Menurut Young dan O’Byne (2001:26) Market value added merupakan perbedaan nilai pasar perusahaan (termasuk ekuitas dan utang) dengan modal keseluruhan yang di investasikan dalam perusahaan". Menurut Brigham dan Houston (2001:50) Market value added dapat di hitung dengan memakai rumus sebagai berikut:

"MVA=Nilai pasar ekuitas-Modal ekuitas yang diinvestasikan oleh investor

atau

$=($ jumlah saham yang beredar $)($ harga saham)-total ekuitas"

\subsection{Profitabilitas"}


Profitabilitas, adalah rasio yang di gunakan untuk me ngukur kompetensi perusaha an dalam meng hasilkan ke untungan dari kegiatan biasa bisnis nya (Hery, 2016:192). Rasio profitabilitas bisa di gunakan sebagai alat untuk menaksir tahap ke efektivitasan kinerja manajemen. performa yang bagus akan memperlihatkan melalui ke berhasilan manajemen dalam memperoleh keuntungan yang di upayakan oleh perusaha an.

Dalam riset ini "rasio profitabilitas yang di gunakan merupakan Return on Equity atau hasil pe ngembalian dari ekuitas). Hasil pengembalian atas ekuitas adalah rasio yang memperlihatkan se berapa besar partisipasi ekuitas dalam menghasilkan laba bersih (Hery, 2016:194). Semakin besar pe ngembalian dari modal artinya semakin besar jumlah laba bersih yang di hasilkan dari setiap dana yang ter tanam dalam ekuitas atau modal. Sebaliknya, semakin rendah hasil pe ngembalian atas ekuitas berarti semakin rendah pula jumlah laba bersih yang di hasilkan dari setiap rupiah dana yang tertanam dalam ekuitas" . Berikut ini merupakan rumus yang digunakan untuk menghitung hasil pengembalian atas ekuitas:

Return on Equity $(\mathrm{ROE}) \frac{\text { laba bersih }}{\text { total ekuitas }}$

\section{Metode Penelitian}

\subsection{Populasi Penelitian}

\section{Hasil Penelitian/Temuan (Finding) \\ 4.1. Statistik Deskriptif}

Tabel 1.Analisis Deskriptif

Descriptive Statistics

\begin{tabular}{|l|r|r|r|r|r|}
\hline & N & Minimum & Maximum & Mean & Std. Deviation \\
\hline Market Value & 57 & 25,80 & 34,50 & 30,8321 & 2,42624 \\
Added & & & & & \\
Return on Equity & 57 &, 42 & 25,99 & 7,6391 & 5,32632 \\
Price to Book & 57 &, 21 & 6,67 & 1,2267 & 1,47071 \\
Value & & & & & \\
Valid N (listwise) & 57 & & & & \\
\hline
\end{tabular}

Berdasarkan tabel 1. diatas bisa di ketahui bahwa jumlah $\mathrm{N}$ dalam studi ini berjumlah 57 data. Dari 57 data sampel variabel dependen, nilai rata-rata dari price to book value positif, dapat dilihat bahwa variabel price to book value mempunyai nilai terendah 0,21 dan nilai tertinggi sebesar 6,61 dengan nilai rata-ratanya sebesar 1,2267 dan standar deviasinya (tingkat sebaran datanya) sebesar 1,47071.
Menurut (Sujarweni, 2015: 80), "Populasi merupakan keseluruhan jumlah yang terdiri atas objek atau subjek yang mempunyai karakteristik dan kualitas tertentu yang ditetapkan oleh peneliti untuk diteliti dan kemudian ditarik kesimpulan". Penelitian ini memiliki populasi semua perusaha an kontruksi dan bangunan yang ter catat di Bursa Efek Indonesia pada tahun 2016-2018 yang ber jumlah 56 perusahaan.

\subsection{Sampel Penelitian}

Menurut (Sujarweni,2015:81), "Sampel adalah bagian dari sejumlah karakteristik yang dimiliki oleh populasi yang digunakan untuk penelitian. Pengambilan sampel pada perusahaan kontruksi bangunan yang konsisten terdaftar di BEI yaitu sejumlah 19 perusahaan di BEI periode 2016-2018".

\subsection{Teknik Pengumpulan Data}

Teknik pengumpulan data dilakukan dengan mengambil studi dokumentasi seperti informasi yang telah di siapkan dan di olah dari bahan laporan jadi yang di dapatkan dari buku, jurnal, penelitian ter dahulu dan laporan keuangan tahunan perusahaan sektor kontruksi bangunan yang ter daftar di Bursa Efek Indonesia (BEI) tahun 2016-2018 melalui situs langsung perusahaan www.idx.co.id 
sebesar 25,99 dengan nilai rata-ratanya sebesar 7,6391 dan standar deviasinya (tingkat sebaran datanya) sebesar 5,32632.

\subsection{Uji Asumsi Klasik}

\subsubsection{Uji Normalitas}

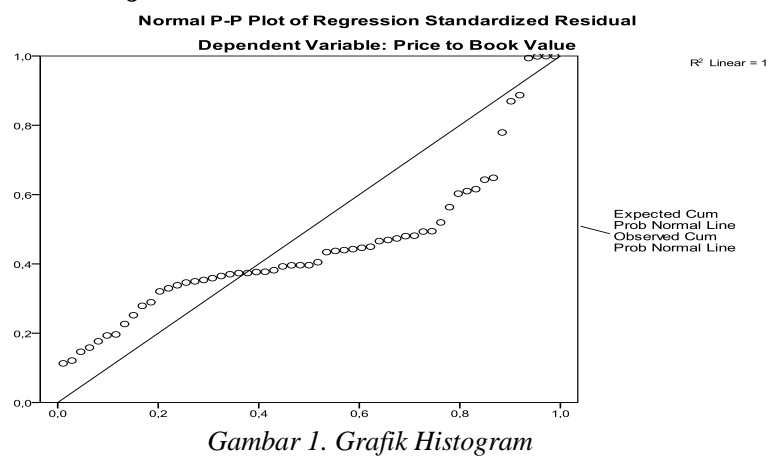

Dari Gambar 1. grafik histogram diatas, bisa dilihat bahwa titik-titik menyebar sekitar garis dan menyusul garis diagonal maka nilai residual telah normal.

\subsubsection{Uji Multikolinearitas}

Tabel 2. Hasil Uji Multikolinearitas

\begin{tabular}{|l|l|c|c|}
\hline \multicolumn{2}{|c|}{ Model } & \multicolumn{2}{c|}{ Collinearity Statistics } \\
\cline { 3 - 4 } & & Tolerance & VIF \\
\hline 1 & Market value added & .999 & 1.002 \\
2 & Return on Equity & .999 & 1.002 \\
\hline
\end{tabular}

a. Dependent Variable: Price to book value Sumber : data diolah, 2021.

1). Nilai VIF dari nilai market value added dan Return on Equity lebih kecil atau di bawah 10, ini berarti tidak terkena multikolinearitas antara variabel independen dalam model regresi.

2). Nilai tolerance dari nilai market value added dan Return on Equity lebih besar dari 0,1 , ini berarti tidak terdapat multikolinearitas antar variabel independen dalam model regresi.

\subsubsection{Uji Heteroskedastisitas}

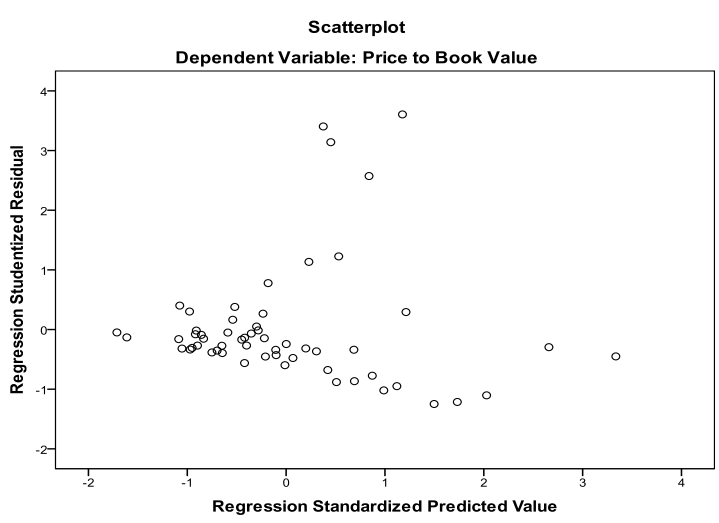

Gambar 2 Heteroskedastisitas

Berdasarkan Gambar 2 dapat terlihat bahwa tidak ada pola yang jelas, serta titik-titik menyebar di atas dan di bawah angka 0 pada sumbu Y, maka berdasarkan metode grafik tidak terjadi heteroskedastisitas pada model regresi.

\subsubsection{Uji Autokorelasi}

Tabel 3. Hasil Uji Autokorelasi Model Summary ${ }^{\mathrm{b}}$

\begin{tabular}{|l|r|r|r|r|r|}
\hline Model & $\mathrm{R}$ & $\mathrm{R}$ Square & $\begin{array}{c}\text { Adjusted R } \\
\text { Square }\end{array}$ & $\begin{array}{c}\text { Std. Error of the } \\
\text { Estimate }\end{array}$ & $\begin{array}{c}\text { Durbin- } \\
\text { Watson }\end{array}$ \\
\hline 1 &, $354^{\mathrm{a}}$ &, 125 &, 093 & 1,40067 & 1,328 \\
\hline
\end{tabular}

a. Predictors: (Constant), Return on Equity, Market Value Added

b. Dependent Variable: Price to Book Value 
Nilai Durbin - Watson hitung adalah sebesar 1,328 lebih besar dari batas atas (du) yakni 1.449 dan kurang dari (4-du) 4-1.449= 2.551. Maka sebagaimana dasar pengambilan keputusan dalam uji durbin watson di atas, dapat disimpulkan bahwa tidak terdapat gejala

\subsection{Analisis Regresi Linear Berganda}

Tabel 4. Hasil Uji Regresi Linier Berganda

Coefficients $^{\mathrm{a}}$

\begin{tabular}{|c|c|c|c|c|c|c|}
\hline \multirow{2}{*}{\multicolumn{2}{|c|}{ Model }} & \multicolumn{2}{|c|}{$\begin{array}{l}\text { Unstandardized } \\
\text { Coefficients }\end{array}$} & \multirow{2}{*}{$\begin{array}{c}\begin{array}{l}\text { Standardized } \\
\text { Coefficients }\end{array} \\
\text { Beta }\end{array}$} & \multirow[b]{2}{*}{$\mathrm{t}$} & \multirow[b]{2}{*}{ Sig. } \\
\hline & & B & Std. Error & & & \\
\hline \multirow[t]{3}{*}{1} & (Constant) & $-1,531$ & 2,392 & &,- 640 &, 525 \\
\hline & $\begin{array}{l}\text { Market Value } \\
\text { Added }\end{array}$ & ,067 & ,077 & , 110 & ,864 & ,391 \\
\hline & Return on Equity & ,092 & ,035 & ,332 & 2,609 &, 012 \\
\hline
\end{tabular}

a. Dependent Variable: Price to Book Value

Sumber : data diolah, 2021.

Tabel di atas menunjukkan bahwa persamaan analisis regresi berganda yaitu :

$$
\mathrm{Y}=-1.531+0.067 \mathrm{X}_{1}+0.092 \mathrm{X}_{2}+\mathrm{e}
$$

1) Nilai independen variabel market value added sebesar 0,067 dan variabel return on equity sebesar 0,092. Dalam hal ini $\mathrm{X}_{1}$ dan $\mathrm{X}_{2}$ sama dengan 0 maka price to book value akan bertambah sebesar 1.531.

2) $X 1$ adalah variabel market value added yang memiliki nilai koefisien regresi sebesar 0,067 . Hal ini bertanda positif yang autokorelasi. Dengan demikian maka analisis regresi linier berganda untuk uji hipotesis penelitian di atas dapat dilakukan atau dilanjutkan."

4.4. Uji Hipotesis

\subsubsection{Uji (T)}

Tabel 5. Hasil Uji t

Coefficients $^{\mathrm{a}}$

\begin{tabular}{|c|c|c|c|c|c|c|}
\hline \multirow[t]{2}{*}{ Mod } & & \multicolumn{2}{|c|}{$\begin{array}{c}\text { Unstandardized } \\
\text { Coefficients }\end{array}$} & $\begin{array}{l}\text { Standardized } \\
\text { Coefficients }\end{array}$ & \multirow[b]{2}{*}{$\mathrm{t}$} & \multirow[b]{2}{*}{ Sig. } \\
\hline & & B & Std. Error & Beta & & \\
\hline \multirow[t]{3}{*}{1} & (Constant) & $-1,531$ & 2,392 & &,- 640 &, 525 \\
\hline & $\begin{array}{l}\text { Market Value } \\
\text { Added }\end{array}$ & ,067 & ,077 & 110 & 864 & 391 \\
\hline & Return on Equity & ,092 & ,035 & ,332 & 2,609 & ,012 \\
\hline
\end{tabular}

a. Dependent Variable: Price to Book Value

Sumber : data diolah, 2021.

Dari nilai t-tabel dengan derajat bebas 57 $2=55$ dan taraf nyata $5 \%$ adalah 2,002. Untuk nilai Market value added $\left(\mathrm{X}_{1}\right)$ diperolah hasil sebesar 0,864 < 2,002 dan nilai Sig $(0,391$ $>$ 0,05), maka Market value added tidak berpengaruh signifikan terhadap price to book berarti memiliki hubungan yang searah yang artinya setiap kenaikan sebesar $1 \%$ maka akan menambah jumlah price to book value sebesar 0.067 .

3) $\mathrm{X}_{2}$ adalah variabel return on equity yang memiliki nilai sebesar 0,092 yang bertanda positif berarti memiliki hubungan yang searah yang artinya setiap kenaikan sebesar $1 \%$ akan menambah jumlah price to book value sebesar 0.092 . value. Untuk nilai Return on Equity $\left(\mathrm{X}_{2}\right)$ diperolah hasil sebesar 2,609 > 2,002 dan nilai Sig $(0,012<0,05)$, maka Return on Equity berpengaruh positif dan signifikan terhadap price to book value." 
Tabel 6. Hasil Uji F

ANOVA $^{\mathrm{b}}$

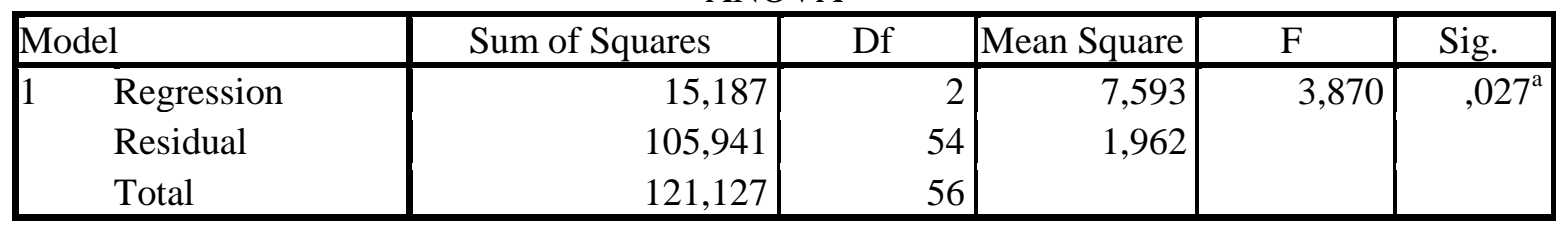

a. Predictors: (Constant), Return on Equity, Market Value Added

b. Dependent Variable: Price to Book Value

Sumber : data diolah, 2021.

Dari uji ANOVA atau $\mathrm{F}$ test, didapat $\mathrm{F}_{\text {hitung }}$ sebesar 3,870 dengan tingkat signifikansi 0,027 . Jadi $F_{\text {hitung }}>F_{\text {tabel }}(3,870>2,18)$ atau sig $\alpha 0,05(0,027<0,05)$. Artinya bahwa secara bersama-sama variabel Market value added, Return on Equity berpengaruh signifikan terhadap price to book value.

\subsubsection{Uji Determinasi $\left(R^{2}\right)$}

Tabel 7. Hasil Koefisien Determinasi Model Summary

\begin{tabular}{|l|r|r|r|r|c|}
\hline Model & $\mathrm{R}$ & $\mathrm{R}$ Square & $\begin{array}{c}\text { Adjusted R } \\
\text { Square }\end{array}$ & $\begin{array}{c}\text { Std. Error of the } \\
\text { Estimate }\end{array}$ & $\begin{array}{c}\text { Durbin- } \\
\text { Watson }\end{array}$ \\
\hline 1 &, $354^{\mathrm{a}}$ &, 125 &, 093 & 1,40067 & 1,328 \\
\hline
\end{tabular}

a. Predictors: (Constant), Return on Equity, Market Value Added

b. Dependent Variable: Price to Book Value

Sumber : data diolah, 2021.

Dari tabel diatas, memperlihatkan nilai koefisien determinasi diperoleh sebesar 0,125 atau sebesar $12,5 \%$. Hal ini menunjukkan market value added dan return on equity berkontribusi sebesar 12,5\% terhadap Price to book value sedangkan sisanya sebesar $87,5 \%$ dipengaruhi oleh variabel lain yang tidak diteliti dalam penelitian ini."

\section{Kesimpulan}

Berdasarkan hasil pengujian hipotesis dan mengacu pada perumusan serta tujuan dari penelitian ini, maka dapat ditarik kesimpulan sebagai berikut:

1) Hasil penelitian menunjukkan bahwa Market Value Added berpengaruh positif dan signifikan terhadap nilai perusahaan pada perusahaan kontruksi bangunan yang terdaftar di Bursa Efek Indonesia.

2) Hasil penelitian menunjukkan bahwa Retrun on equity berpengaruh positif dan signifikan terhadap nilai perusahaan pada perusahaan kontruksi bangunan yang terdaftar di Bursa Efek Indonesia

3) Hasil penelitian menunjukkan bahwa secara bersama sama Market Value Added dan Retrun on equity berpengaruh terhadap nilai perusahaan pada perusahaan kontruksi bangunan yang terdaftar di Bursa Efek Indonesia.

\section{DAFTAR PUSTAKA}

Abdul Syukur. (2018).'Pengaruh Economic Value Added Dan Market value added Terhadap Nilai Perusahaan Pada Perusahaan Manufaktur Sub Sektor Makanan dan Minuman Yang Terdaftar Di BEI” . Dinamic Management Journal Vol.3 No. 02 .

Abdul Kohar. (2019).’Pengaruh Struktur Modal, Likuiditas Terhadap Nilai Perusahaan Subsektor Kontruksi Bangunan di Bursa Efek Indonesia". Jurnal Ekonomi dan Akuntansi Volume 3 No 2

“Azid,T.,Austay,M., \& Burki,U. (2007). Theory of The Firm,Management and Stakeholders:An Islamic Prespective. Islamic Economic."

"Brigham, Eugene F, dan Joel. Huston. (2001). Manajemen Keuangan(Edisi VIII .). Jakarta: Erlangga."

"Bayu Irfandi Wijaya, I. B. Panji Sedana. (2015). Pengaruh Profitabilitas Terhadap Nilai Perusahaan (Kebijakan Dividen dan Kesempatan Investasi Sebagai Variabel Mediasi). E-Jurnal Manajemen Unud Volume" 4 No 2, 4477-4500. 
Beny Mulyadi Sukandar, Noer Azam Achsani, Roy Sembel, Bagus Sartono. (2018). Efisiensi Perusahaan Kontruksi Bangunan. Jurnal Ilmiah Manajemen Volume 8, No 3, 628-639.

Cut Sarah Syahirah,Maya Febriyanti Lantania. (2016). Pengaruh Market value added,Economic Value Added,Kebijakan Dividen dan Kepemilikan Manajerial Terhadap Nilai Perusahaan Pada Perusahaan Manufaktur Yang Terdaftar Di Bursa Efek Indonesia. Jurnal Ilmiah Mahasiswa Ekonomi Akuntansi Vol.1 No.1, Halaman 1-12.

Ghozali,Imam. (2013). “Aplikasi Analisis Multivariate dengan program SPSS 19. Semarang: Badan Penerbit Universitas Diponegoro."

"Hermuningsih, Sri dan D. K Wardani. (2009). Faktor-Faktor Yang Mempengaruhi Nilai Perusahaan Pada Perusahaan Yang terdaftar di Bursa Efek Malaysia dan Bursa Efek Indonesia . Jurnal Siasat Bisnis13(2), 173183."

"I Gusti Ngurah Agung Dwi Pramana, I Ketut Mustanda. (2016). Pengaruh Profitabilitas dan Size Terhadap Nilai Perusahaan Dengan CSR Sebagai Variabel Pemoderasi. E- Jurnal Manajemen Unud Vol 5 No 1," Halaman 561-594.

"I Putu Hendra Sintyana, Luh Gede Sri Artini. (2019). Pengaruh Profitabilitas, Struktur Modal, Ukuran Perusahaan dan Kebijakan Dividen Terhadap Nilai Perusahaan. Jurnal Manajemen Volume 8 No 2."

"Keown,Arthur J dkk. (2010). Financial Manajemen: Principal and Application. Terjemahan oleh Marcus Prihminto Widodo. Jakarta: INDEKS."

Laili Monita Wulandari. (2020). "Pengaruh Profitabilitas,Investment Opportunity Set,Market value added Terhadap Return Saham Syariah Dengan Nilai Perusahaan Sebagai Variabel Intervening."

"Mardiyati,Umi. (2015). "Pengaruh Keputusan Investasi,Keputusan Pendanaan, Ukuran" Perusahaan dan Profitabilitas terhadap Nilai Perusahaan Pada Sektor Manufaktur Barang Konsumsi yang terdaftar di Bursa Efek Indonesia." Jurnal Riset Manajemen Sains Indonesia, Vol. 6 No.1, 420.

Ninin Non Ayu Salmah, Sri Ermelia. (2019). "Determinan Struktur Modal Perusahaan Subsektor Kontruksi Bangunan di Bursa
Efek Indonesia . Jurnal Ekonomi dan Bisnis Volume 3 No 2."

"Octavia Languju,Maryam Mangantar,Hizkia H. D.Tasik. (2016). Pengaruh Return on Equity,Ukuran Perusahaan,Price earning ratio Dan Struktur Modal Terhadap Nilai Perusahaan Property And Real Eastate Terdaftar Di Bursa Efek Indonesia. Jurnal Berkala Ilmiah Efisien Vol.16 No 02."

"Rahayu, S. (2010). Pengaruh Kinerja Keuangan Terhadap Nilai Perusahaan dengan Pengungkapan Corporate Social Responsibility dan Good Corporate Governance sebagai variabel moderasi. Skripsi Fakultas Ekonomi Universitas Negeri Semarang."

"Sujarweni. (2015). Metode Penelitian:Bisnis\& Ekonomi.Yogyakarta: Pustaka Baru Press."

"Suroto. (2018). Analisis Faktor- Faktor yang Mempengaruhi Nilai Perusahaan Studi empiris pada Perusahaan LQ-45. Jurnal Ilmiah UNTAG, Vol.7 No.2, 99."

"Wardani, S. H.\& Kusuma, D. (2007). FaktorFaktor yang Mempengaruhi Nilai Perushaan pada Perusahaan yang Terdaftar di Bursa Efek Malaysia dan Bursa Efek Indonesia. Siasat Bisnis," 173-183.

"Yessica Tria Christia,Erni Ekawati. (2014). Excess Cash Holdings dan Kepemilikan Institusional Pada Perusahaan Manufaktur yang Terdaftar di BEI. Jurnal Manajemen Strategi Bisnis dan Kewirausahaan "Volume 8 No 1.

Yoga Pradipta Wibawa. (2018). "Pengaruh Kinerja Keuangan Terhadap Nilai Perusahaan Sektor Properti yang Terdaftar di Bursa Efek Indonesia." 